\title{
Do Tourism Vocational High School Students in Medan Know About MICE?
}

\author{
Sarah Rouli Tambunan ${ }^{1 *}$, Anggiat Parlindungan ${ }^{2}$ \\ \{sarahroulitambunan@polmed.ac.id ${ }^{1}$, anggiatparlindungan@polmed.ac.id ${ }^{2}$ \} \\ Politeknik Negeri Medan, Padang Bulan Medan, Indonesia \\ *sarahroulitambunan@polmed.ac.id
}

\begin{abstract}
Increasing tourism revenue from MICE sector is currently being driven by the government, therefore human resources in tourism based MICE sector are needed. MICE Study Program of Politeknik Negeri Medan was established in 2007. One of the potential student targets for this department is tourism vocational high school students, because MICE industry is related to tourism. Based on the number active students in MICE study program, there are only 3 students who graduated from tourism vocational high school, while in Medan, there are 15 tourism vocational high school. This article wants to discuss: do tourism vocational high school students in Medan know about MICE industry and the role of university in socializing MICE in Medan.
\end{abstract}

Keywords: mice, tourism vocational high school

\section{Introduction}

The Indonesian government is currently starting to focus on developing the tourism based on MICE sector. This is evidenced by the determination of the target number of MICE tourists by 2 million MICE tourists in 2019. MICE tourists are considered attractive because of the different characteristics of ordinary tourists. MICE tourists combine business and leisure activities, so the duration of the visit can be longer and their expenses can reach 7 times greater than ordinary tourists.

The manifestation of the government's attention in developing MICE industry is shown by setting 16 MICE destinations as Jakarta, Bali, Surabaya, Medan, Batam, Padang, Bandung, Yogyakarta, Semarang, Makassar, Manado, Lombok, Solo, Bintan, Palembang and Balikpapan. From a number of cities above only Jakarta and Bali are included in the category of existing destinations and always top the list of ICCA as the destinations that hold many MICE events. The success of Jakarta and Bali is supported by the presence of infrastructure as facilities for large-scale and international events.

Medan as a MICE destination is still unable to compete with Jakarta and Bali in the infrastructure, but Medan is one of the cities that produce skilled human resources in the field of MICE in Indonesia, which is marked by the establishment of the Meeting, Incentive Travel, Convention Exhibition (MICE) study program at Politeknik Negeri Medan (Polmed). This study program was established in accordance with decree No. 2155 / D / T / 2007. 
The term MICE may not be too familiar to prospective new students. In fact, many MICE Polmed students only know the term MICE when filling in the registration form for Polytechnic entrance exams. The public is more familiar with the term tourism which is the root of MICE itself.

One of the targets that can be influenced to increase the number MICE study program students is tourism vocational high school students, because their learning connect to the MICE industry. However, the data shows that from the three batches of students in MICE study program (2016-2018) with a total of 175 students, only 3 students have graduated from tourism vocational schools in Tourism.

Awareness of various parties about MICE needs to get serious attention especially for those who connect with the world of tourism such as tours vocational high school graduates because they play a role as human resources who contribute in supporting MICE tourism in the city of Medan. Tourism vocational high school students are usually faced with 3 choices: continuing education to college, working, or doing business. For graduates who want to go to college, knowledge of MICE can add references to educational choices that answer the needs of human resources in the MICE field. Meanwhile, for them who want to work or be entrepreneurs, knowledge of MICE is very necessary to synchronize between graduates and the needs of the tourism based MICE industry that is currently being developed by the government in Medan intensively.

Based on the phenomena described earlier, this article will discuss the knowledge of tourism vocational school students in Medan and the role of universities in socializing MICE in Medan.

\section{Analysis and Discussion}

\subsection{Do Vocational High School Students in Medan Know About MICE?}

Vocational education is education that provides students with various kinds of knowledge, skills and experience so that they are able to do certain jobs needed, both for themselves, for the world of work, and for the development of their nation [1]. Vocational School graduates are mid-level workers who have sufficient skills or competencies in accordance with the guidance of the times, and are ready to work in the business world and the industry.

Arikunto in Muniarti [1], describes the characteristics of vocational education are as follows: Specialized education designed to prepare the learner for entrance into a particular vocation, or to upgrade employed worker

a. Content drawn from the world of work through analysis of the skills understanding, values and attitudes of successful workers in a particular field

b. Instruction organized into sequences of courses and at preparation for a particular occupation or family occupations

c. Emphasis on job preparation or advancement in employment

The tourism is the second most popular field in the vocational school in Indonesia. According to data from the Central Statistics Agency (BPS) approximately 83,000 vocational graduates were born from tourism. One of the factors that caused students want to choose this field is because of the perception of having fun and traveling. There are nine majors in the field of tourism that can be selected by prospective vocational students [2]: 
Table 1. Majors in The Field of Tourism

\begin{tabular}{|c|c|c|c|}
\hline No. & Field of Tourism & & Majors \\
\hline 1. & Business Travel Services & $\begin{array}{l}\text { a) } \\
\text { b) } \\
\text { c) } \\
\text { d) }\end{array}$ & $\begin{array}{l}\text { Business Travel Services } \\
\text { Hospitality } \\
\text { Maritime Tourism } \\
\text { Ecotourism }\end{array}$ \\
\hline 2. & Culinary & a) & Catering \\
\hline 3. & Beauty & $\begin{array}{l}\text { a) } \\
\text { b) }\end{array}$ & $\begin{array}{l}\text { Skin and Hair Beauty } \\
\text { Spa and Beauty Therapy }\end{array}$ \\
\hline 4 & Clothing & $\begin{array}{l}\text { a) } \\
\text { b) }\end{array}$ & $\begin{array}{l}\text { Fashion } \\
\text { Fashion Design }\end{array}$ \\
\hline
\end{tabular}

In the city of Medan, there are 15 registered vocational schools registered at the Directorate of Vocational Development [3], as:

Table 2. List of Tourism Vocational School in Medan

\begin{tabular}{|c|c|c|c|c|c|c|}
\hline NO & NPSN & Voc.Schools & Status & Province & City & $\begin{array}{l}\text { Field of } \\
\text { Study }\end{array}$ \\
\hline 1 & 10211265 & $\begin{array}{l}\text { SMKS } \\
\text { PENCAWAN } 1\end{array}$ & Private & $\begin{array}{l}\text { North } \\
\text { Sumatera }\end{array}$ & Medan & Tourism \\
\hline 2 & 69954155 & $\begin{array}{l}\text { SMK SWASTA } \\
\text { TRITECH } \\
\text { INDONESIA }\end{array}$ & Private & $\begin{array}{l}\text { North } \\
\text { Sumatera }\end{array}$ & Medan & Tourism \\
\hline 3 & 10211269 & $\begin{array}{l}\text { SMKS RAKSANA } \\
2\end{array}$ & Private & $\begin{array}{l}\text { North } \\
\text { Sumatera }\end{array}$ & Medan & Tourism \\
\hline 4 & 10259159 & $\begin{array}{l}\text { SMKS } \\
\text { INDONESIA } \\
\text { MEMBANGUN } 3\end{array}$ & Private & North & Medan & Tourism \\
\hline 5 & 10259305 & $\begin{array}{l}\text { SMKS SHANDHY } \\
\text { PUTRA } 2\end{array}$ & Private & $\begin{array}{l}\text { North } \\
\text { Sumatera }\end{array}$ & Medan & Tourism \\
\hline 6 & 10210978 & SMKN 7 MEDAN & Public & $\begin{array}{l}\text { North } \\
\text { Sumatera }\end{array}$ & Medan & Tourism \\
\hline 7 & 69886449 & $\begin{array}{l}\text { SMKS IT } \\
\text { MARINAH AL- } \\
\text { HIDAYAH }\end{array}$ & Private & $\begin{array}{l}\text { North } \\
\text { Sumatera }\end{array}$ & Medan & Tourism \\
\hline 8 & 69949521 & $\begin{array}{l}\text { SMKS SETYA } \\
\text { NUSANTARA } \\
\text { MEDAN }\end{array}$ & Private & $\begin{array}{l}\text { North } \\
\text { Sumatera }\end{array}$ & Medan & Tourism \\
\hline
\end{tabular}




\begin{tabular}{|c|c|c|c|c|c|c|}
\hline NO & NPSN & Voc.Schools & Status & Province & City & $\begin{array}{l}\text { Field of } \\
\text { Study }\end{array}$ \\
\hline 9 & 10210976 & SMKN 1 MEDAN & Public & $\begin{array}{l}\text { North } \\
\text { Sumatera }\end{array}$ & Medan & Tourism \\
\hline 10 & 10210765 & SMKN 8 MEDAN & Public & $\begin{array}{l}\text { North } \\
\text { Sumatera }\end{array}$ & Medan & Tourism \\
\hline 11 & 69938168 & $\begin{array}{l}\text { SMK SWASTA } \\
\text { PARIWISATA } \\
\text { IMELDA }\end{array}$ & Private & $\begin{array}{l}\text { North } \\
\text { Sumatera }\end{array}$ & Medan & Tourism \\
\hline 12 & 69900263 & $\begin{array}{l}\text { MANAJEMEN } \\
\text { PENERBANGAN } \\
\text { MEDAN }\end{array}$ & Private & $\begin{array}{l}\text { North } \\
\text { Sumatera }\end{array}$ & Medan & Tourism \\
\hline 13 & 10210769 & $\begin{array}{l}\text { SMKS CIPTA } \\
\text { KARYA }\end{array}$ & Private & $\begin{array}{l}\text { North } \\
\text { Sumatera }\end{array}$ & Medan & Tourism \\
\hline 14 & 69728769 & $\begin{array}{l}\text { SMKN } 13 \\
\text { MEDAN }\end{array}$ & Public & $\begin{array}{l}\text { North } \\
\text { Sumatera }\end{array}$ & Medan & Tourism \\
\hline 15 & 10211074 & $\begin{array}{l}\text { SMKN } 10 \\
\text { MEDAN }\end{array}$ & Public & $\begin{array}{l}\text { North } \\
\text { Sumatera }\end{array}$ & Medan & Tourism \\
\hline
\end{tabular}

Based on a survey that the author conducted on tourism vocational school students in Medan with 150 respondents, there are 78 peoples $(58 \%)$ who had heard of the MICE industry, but only 23 peoples $(29.48 \%)$ could correctly mention MICE's length, 53 peoples $(67.94 \%)$ were wrong and 2 peoples were unable to mention it.

Furthermore, respondents who had heard about the MICE industry knew MICE from their learning in schools as many as 70 peoples $(925), 2$ peoples $(2.63 \%)$ got information from the mass media, while 4 peoples $(5.25 \%)$ knew MICE from other sources as family, friends, etc.

Based on the data above, it can be seen that although the MICE industry is learnt at school, not all students are able to explain what MICE is. In fact, there are still students who have never heard about MICE, even though the tourism sector is connected with MICE and is the focus of the current government.

The low awareness of vocational students in the field of tourism based on MICE could have an impact on the absorption of vocational graduates in the MICE industry. MICE industry related to tourism in several field such as transportation, accommodation, food and beverage. The need for educational programs that are relevant to the demands and development of the times is increasingly important. Promoting collaboration between vocational schools and industry is an effective way to improve the quality of vocational school graduates.

Based on the research the author conducted, only 9 peoples $(6,42 \%)$ of vocational students are interested in continuing their education in the MICE study program in Medan, they are more interested in entering the Medan Tourism Polytechnic because they feel linear with their majors. This is due to their ignorance of the existence of the MICE study program at Medan State Polytechnic. From 150 respondents only 48 peoples (32\%) of respondents who knew that there is a MICE study program in Medan. This has an impact on the study program is more dominant filled by high school students, rather than tourism vocational high school and also has an impact on their sentiments on learning material in college. 


\subsection{The Role of Universities in Socializing MICE}

Kesrul [4], stated that MICE as a tourism activity, combination of leisure and business, usually involves a group of people together, a series of activities in the form of meetings, incentive travel, conventions, congresses, conferences, and exhibitions. The development of the MICE industry as a new industry that can benefit many parties, because the MICE industry is a complex industry and involves many parties. Therefore MICE industry in Indonesia can support the development of Indonesian tourism widely [5].

The existence of universities is expected to be able to play an active role in realizing Medan as a MICE city. Arief Yahya (tourism minister for the period 2014-2019) explained that to create a positive development of the tourism sector, synergy is needed from the five main tourism stakeholders called penthalix, namely academics, business people, government, communities, and the media.

The stretching of MICE industry development has encouraged universities to open MICE study programs such as Politeknik Negeri Medan. Besides it, MICE as a subject is also taught in tourism study programs in Indonesia. This shows that universities see opportunities for reliable human resources to support government programs in developing MICE industry in Indonesia in the future.

As a study program that has been established since 2007, MICE Polmed study program needs to be active in introducing MICE to tourism vocational school students. The trick is to actively socialize about the MICE industry and future employment prospects.

Polmed also needs to be a government partner to socialize Medan as a MICE city to all levels of society in Medan, so that the community also participates in building the MICE industry in Medan.

In order to produce reliable human resources in the MICE field, MICE Polmed's study program can also provide training to encourage workers in the MICE field that are certified. All of this can be realized in community service programs as a form of higher education.

\section{Conclusion}

Awareness of the MICE industry in Medan needs to be increased especially for those who are involved in the tourism world such as tourism vocational students. Although they have learnt about MICE, not all students can explain what MICE is. The survey also showed that very few of tourism vocational school students knew about MICE study program in Medan, which had an impact on the lack of interest in students who wanted to continue their studies at MICE study program of Politeknik Negeri Medan.

Politeknik Negeri Medan needs to be active in socializing the MICE industry and future employment prospects as well as training for tourism vocational students in Medan to encourage the presence of certified human resources in the MICE-based tourism sector. 


\section{References}

[1] Muniarti, Usman Nasir.: Implementasi Manajemen Stratejik Dalam Pemberdayaan Sekolah Menegah Kejuruan.p 112. Citapustaka Media Perintis, Bandung. (2009)

[2] https://rencanamu.id/post/dunia-sekolah/akademik/serba-serbi-smk-bidang-dan-jurusansmk-pariwisata

[3]http://datapokok.ditpsmk.net/rombel?id_prov $=070000 \& i d \_k a b=076000 \& i d \_k e c=\& i d \_b i d a$ $\mathrm{ng}=40 \&$ id_program $=\&$ id_kompetensi $=\& \mathrm{sts}=\&$ cari $=$

[4] Nirwandar,Sapta.:Building WoW Indonesia Tourism And Creative Industry.p 113.Gramedia Pustaka,Jakarta. (2014)

[5] Luturlean, Bachruddin Saleh.: Strategi Bisnis Pariwisata. p196. Humaniora, Bandung. (2019) 